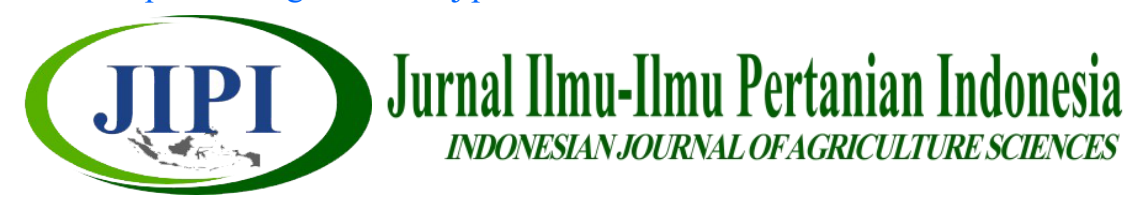

\title{
PERTUMBUHAN VEGETATIF BIBIT JERUK GERGA PASCA OKULASI PADA KONSENTRASI PUPUK ORGANIK CAIR YANG BERBEDA
}

\author{
Lia Resti Utami ${ }^{1}$, Yulian ${ }^{{ }^{*}}$, Bambang Sulistyo ${ }^{2}$ \\ ${ }^{1}$ Program Studi Agroekoteknologi, Fakultas Pertanian Universitas Bengkulu \\ ${ }^{1}$ Program Studi Ilmu Tanah, Fakultas Pertanian Universitas Bengkulu \\ *Corresponding Author : yulian@unib.ac.id
}

\begin{abstract}
[VEGETATIVE GROWTH OF GRAFTING SEEDLINGS OF GERGA ORANGE IN DIFFERENT CONCENTRATIONS OF LIQUID ORGANIC FERTILIZER]. This study aims to examine explain the effect of gamal leaf liquid organic fertilizer dosage, the way of application of gamal leaf liquid organic fertilizer, and the interaction between treatments on the growth of citrus plants. This research was conducted from August to December 2017 at the Greenhouse of the Faculty of Agriculture, University of Bengkulu. This research was carried out using a Randomized Complete Block Design using 2 factors. The first factor is the way the application of gamal leaf liquid organic fertilizer is sprayed on the leaves and watered onto the ground. The second factor is the concentration of gamal leaf liquid organic fertilizer which consists of control, $25 \%, 50 \%, 75 \%$ and $100 \%$. The results showed that application of liquid organic fertilizer only gave effect to the number of branches. The $50 \%$ gamal leaf liquid organic fertilizer concentration was able to increase the number of branches of gerga orange seedlings by an average of 1.04 branches.
\end{abstract}

Keyword: gerga orange, grafting, liquid organic fertilizer

\begin{abstract}
ABSTRAK
Penelitian ini bertujuan untuk menjelaskan pengaruh dosis pupuk organik cair daun gamal, cara aplikasi pupuk organik cair daun gamal, dan interaksi antar perlakuan terhadap pertumbuhan tanaman jeruk gerga. Penelitian ini dilaksanakan pada bulan Agustus sampai dengan Desember 2017 di Rumah Kaca Fakultas Pertanian Universitas Bengkulu. Penelitian ini dilakukan dengan menggunakan Rancangan Acak Kelompok Lengkap (RAKL) dengan menggunakan dua faktor. Faktor pertama aplikasi pupuk organik cair daun gamal terdiri atas dua cara yaitu disemprot di daun dan disiram ke tanah. Faktor kedua yaitu konsentrasi pupuk organik cair daun gamal yang terdiri atas kontrol, $25 \%, 50 \%, 75 \%$, dan $100 \%$. Hasil penelitian menunjukkan bahwa pemberian pupuk organik cair hanya memberi pengaruh terhadap jumlah cabang. Konsentrasi POC 50\% mampu meningkatkan jumlah cabang tanaman jeruk gerga rata-rata sebanyak 1,04 cabang.
\end{abstract}

Kata kunci: jeruk gerga, okulasi, pupuk organik cair 


\section{PENDAHULUAN}

Jeruk yang banyak dikembangkan di Indonesia terdiri atas beberapa jenis, yaitu jeruk manis dan sitrun yang berasal dari Asia Timur atau Cina, jeruk nipis, jeruk purut dan jeruk bali (pamelo) dari Asia Tenggara. Buah jeruk mengandung sumber vitamin C (Endarto \& Martini, 2016). Tanaman jeruk pada umumnya dapat dibudidayakan di daerah tropis dengan ketinggian tempat $650-2000 \mathrm{~m}$ dpl, berbagai jenis tanah mulai dari tanah berpasir hingga tanah liat berat. Tanaman jeruk membutuhkan perairan yang cukup tetapi tidak tergenang, dengan $\mathrm{pH}$ tanah 5 (Purnomosidhi et al., 2007).

Jeruk gerga merupakan salah satu jenis jeruk unggulan di daerah Lebong. Tanaman jeruk gerga memiliki keunggulan yaitu berproduksi sepanjang tahun, warna buah kuning-orange, ukuran buah lebih besar dari jeruk biasanya dan memiliki rasa asam manis dan segar. Luas pertanaman jeruk gerga pada tahun 2012 mencapai 75 ha, sedangkan yang sudah berproduksi seluas 60 ha. Hingga akhir tahun 2012 ditanam 100 ha jeruk gerga dan 200 ha lagi pada tahun 2013 (Rambe et al., 2012).

Perbanyakan tanaman jeruk dapat dilakukan dengan cara generatif maupun vegetatif. Salah satu perbanyakan tanaman secara vegetatif adalah okulasi. Okulasi merupakan salah satu kegiatan menyatukan dua sifat baik tanaman yaitu tanaman yang memiliki perakaran yang kuat dan tumbuh subur disatukan dengan tanaman yang buahnya bermutu tinggi (Wudiyanto, 2002). Ada beberapa keuntungan bibit hasil okulasi yaitu memperoleh batang bawah dengan perakaran yang kuat, memperoleh tumbuhan yang sesuai dengan keinginan, biaya lebih murah, mempercepat periode produktif, dan bahan tanaman induk yang digunakan tidak terlalu banyak namun menghasilkan bibit yang banyak (Hartaman et al., 1990). Keunggulan okulasi dibandingkan dengan perbanyakan yang lainnya yaitu mudah dilakukan, perakaran kuat, sifatnya sama dengan induknya, dan relatif lebih resisten terhadap hamadan penyakit(Boerhendhy, 2014).

Permasalahan yang dihadapi dalam budidaya tanaman jeruk gerga yang ditemui di lapangan di antaranya adalah dosis pupuk yang spesifik lokasi belum ditemukan, penampilan sebagian buah pucat dan tidak mulus atau kusam sehingga kurang menarik. Harga pupuk dan pestisida yang tinggi membuat para petani kesulitan untuk mendapatkan pupuk yang maksimal dalam usahatani tanaman jeruk gerga (Rambe et al., 2012).

Pemberian pupuk organik yang berasal dari kotoran ternak maupun sisa tanaman dapat memperbaiki sifat fisik, kimia dan biologi tanah (Juarsah, 2014). Pupuk organik dapat berbentuk padat dan cair. Pupuk organik cair merupakan pupuk yang berbentuk cair, dibuat dengan cara mencampurkan kotoran ternak, daun jenis tanaman kacang-kacangan dalam air lalu difermentasikan. Salah satu tanaman yang berpotensi sebagai pupuk organik cair yaitu tanaman gamal. Tanaman gamal merupakan jenis tanaman dari golongan leguminoceae yang mengandung nitrogen cukup tinggi. Daun gamal mengandung $3,15 \% \mathrm{~N}, 0,22 \% \mathrm{P}, 2,65 \% \mathrm{~K}, 1,35 \% \mathrm{Ca}$, dan $0,41 \%$ Mg (Ibrahim, 2002).. Selain itu tanaman gamal juga memiliki keunggulan dibandingkan jenis leguminoceae lainnya yaitu proses budidayanya murah, cepat tumbuh, mengandung $\mathrm{N}$ yang tinggi dengan $\mathrm{C} / \mathrm{N}$ rendah sehingga mudah terdekomposisi (Jusuf et al., 2007). Hasil penelitian Rini (2014) menunjukkan bahwa pemberian pupuk daun gamal menghasilkan rata-rata tinggi tanaman yang lebih tinggi dibandingkan dengan pemberian pupuk dari daun lantoro dan pupuk dari daun jonga-jonga. Kandungan N, P dan K dalam pupuk organik cair yang terbuat dari daun gamal dan limbah ternak memiliki kualitas pupuk cair yang sangat tinggi (Pancapalaga, 2011).

Penelitian ini bertujuan untuk menjelaskan pengaruh dosis pupuk organik cair daun gamal, cara aplikasi pupuk organik cair daun gamal, dan interaksi antar perlakuan terhadap pertumbuhan tanaman jeruk gerga.

\section{METODE PENELITIAN}

Penelitian ini dilaksanakan pada bulan AgustusDesember 2017 di rumah kasa Laboratorium Budidaya Pertanian, Fakultas Pertanian, Universitas Bengkulu. Percobaan disusun atas dasar Rancangan Acak Kelompok Lengkap (RAKL) dengan dua faktor perlakuan. Faktor pertama aplikasi POC yang terdiri atas dua cara yaitu semprot di daun $\left(\mathrm{C}_{1}\right)$ dan siram ke tanah $\left(\mathrm{C}_{2}\right)$. Faktor kedua konsentrasi POC sebanyak 5 taraf yaitu kontrol $\left(\mathrm{K}_{0}\right), 25 \%$ POC $\left(\mathrm{K}_{1}\right)$, $50 \%$ POC $\left(\mathrm{K}_{2}\right), 75 \%$ POC $\left(\mathrm{K}_{3}\right)$, dan $100 \%$ POC $\left(\mathrm{K}_{4}\right)$. Perlakuan diulang sebanyak 3 kali, sehingga diperoleh 30 total tanaman. Penelitian menggunakan polybag dengan ukuran $35 \mathrm{~cm} \times 40 \mathrm{~cm}$. Pupuk organik cair yang digunakan dibuat menggunakan bahan urine sapi $50 \mathrm{~L}$, tanah topsoil $10 \mathrm{~kg}$, kotoran sapi segar $10 \mathrm{~kg}$, daun tanaman gamal $60 \mathrm{~kg}$, larutan EM4 $20 \mathrm{~mL}, 4 \mathrm{~kg}$ gula aren yang dilarutkan dengan air volume $20 \mathrm{~L}$. Secara keseluruhan bahan dicampur dan ditambahkan air hingga volume $200 \mathrm{~L}$, dimasukkan ke dalam drum dan diinkubasikan selama \pm 1 bulan. POC yang sudah berwarna kuning dan mempunyai aroma yang tidak terlalu menyengat, disaring dan siap untuk diaplikasikan (Hadisuwito, 2017).

Pengamatan dilakukan terhadap peubah tinggi tanaman $(\mathrm{cm})$, diameter batang $(\mathrm{mm})$, jumlah daun (helai), luas daun $\left(\mathrm{cm}^{2}\right)$, jumlah cabang, dan tingkat kehijaun daun (klorofil). Data hasil pengamatan dianalisis secara statistik menggunakan analisis varian pada taraf 5\%. Data yang menunjukkan berbeda nyata dilanjutkan dengan uji beda rata-rata BNT dan 
Polinomial Orthogonal untuk interaksi (Gomez \& Gomez, 1983).

\section{HASIL DAN PEMBAHASAN}

Hasil analisis varian pemberian konsentrasi pupuk organik cair daun gamal terhadap pertumbuhan vegetatif bibit jeruk gerga pasca okulasi menunjukkan bahwa perbedaan nyata $(\mathrm{P} \leq 0,05)$ antar perlakuan hanya terlihat pada peubah jumlah cabang. Perlakuan cara pemberian POC dan interaksi antar dua perlakuan yang diuji berbeda tidak nyata $(\mathrm{P}>0,05)$ pada semua peubah. Perbandingan rata-rata antar konsentrasi POC daun gamal terhadap peubah pertumbuhan vegetatif bibit jeruk gerga pasca okulasi seperti terlihat pada Tabel 1.

Tabel 1. Rata-rata pertumbuhan vegetatif bibit jeruk gerga pasca okulasi pada konsentrasi POC yang berbeda

\begin{tabular}{ccccccc}
\hline $\begin{array}{c}\text { Konsentrasi } \\
(\%)\end{array}$ & TT $(\mathrm{cm})$ & $\begin{array}{c}\text { JD } \\
\text { (helai) }\end{array}$ & $\begin{array}{c}\text { DB } \\
(\mathrm{mm})\end{array}$ & JC & $\begin{array}{c}\text { LD } \\
\left(\mathrm{cm}^{2}\right)\end{array}$ & TKD \\
\hline 0 & 27,59 & 22,8 & 4,365 & $0,93 \mathrm{ab}$ & 19,96 & 52,71 \\
25 & 23,43 & 15,1 & 3,81 & $0,76 \mathrm{bc}$ & 24,28 & 60,25 \\
50 & 21,68 & 17,4 & 3,47 & $1,04 \mathrm{a}$ & 17,68 & 53,24 \\
75 & 28,61 & 23,9 & 4,35 & $0,70 \mathrm{c}$ & 22,84 & 54,98 \\
100 & 23,31 & 21,3 & 3,795 & $0,70 \mathrm{c}$ & 17,26 & 56,62 \\
\hline
\end{tabular}

Keterangan : angka-angka yang diikuti oleh huruf yang sama pada kolom yang sama berbeda tidak nyata pada BNT 5\%. TT = tinggi tanaman,

$\mathrm{JD}=$ jumlah daun, $\mathrm{DB}=$ diameter batang, $\mathrm{JC}=$ jumlah cabang

$\mathrm{TKD}=$ tingkat kehijauan daun

Konsentrasi 50\% POC daun gamal mampu menghasilkan jumlah cabang terbanyak rata-rata 1,04 cabang, namun capaian ini berbeda tidak nyata jika dibandingkan dengan yang dihasilkan oleh konsentrasi $0 \%$ POC. Kandungan unsur hara pada POC dapat merangsang pertumbuhan tunas baru untuk membentuk cabang. Pembentukan tunas baru juga dipengaruhi oleh adanya unsur hara dan hormon pertumbuhan seperti sitokinin yang berperan untuk memacu pembentukan tunas (Oviyanti, 2016). Banyak hal yang mempengaruhi keberhasilan pemupukan pada tanaman jeruk seperti jenis, umur, hasil atau biomasa yang dihasilkan tanaman dan faktor lingkungan (Sutopo, 2008). Pada tanaman jeruk belum menghasilkan unsur hara yang diserap diarahkan untuk pembentukan cabang sehingga belum termanfaatkan untuk perkembangan organ tanaman lainnya. Pupuk yang diberikan pada tanaman tahunan akan memberikan respons positif pada tahun berikutnya atau beberapa tahun kemudian (Bhargava, 2002). Semakin tinggi konsentrasi POC tidak diikuti dengan semakin baiknya pertumbuhan bibit jeruk (Tabel 1). Konsentrasi POC daun gamal 75\% mampu menghasilkan tinggi tanaman tertinggi dan jumlah daun terbanyak. Sedangkan konsentrasi POC daun gamal 25\% menghasilkan luas daun dan tingkat kehijauan daun terbesar.
Pemberian POC secara statistik berpengaruh tidak nyata terhadap pertumbuhan tinggi bibit jeruk gerga. Pada saat pengamatan dilakukan daun dan akar belum berkembang dengan baik dan aktif menyerap unsur hara. Penelitian konsentrasi POC terhadap pertumbuhan bibit sengon laut menunjukkan hasil yang nyata pada pengamatan 30 hari setelah sapih (Knaofmone, 2016). Pengaruh pemberian POC terhadap pertumbuhan tinggi tanaman pada minggu ke 1 sampaiminggu ke 5 berjalan sangat lambat, sedangkan pada minggu ke 6 sampai minggu ke 12 perlakuan pertumbuhan tinggi tanaman berjalan lebih cepat. Laju pertumbuhan suatu tanaman pada awalnya akan lambat, namun semakin meningkat dan cepat pertumbuhannya seiring semakin besar suatu tanaman (Salisbusbury \& Ross, 1978).

Pemberian POC daun gamal meningkatkan pertumbuhan jumlah daun pada minggu ke 1 sampai minggu ke 5 secara sangat lambat. Peningkatan jumlah daun terjadi secara cepat pada saat minggu ke 6 sampai minggu ke 12 . Unsur hara pada pupuk organik memerlukan waktu yang cukup pagar dapat diserap oleh tanaman. Penelitian Ohorella (2012) menunjukkan bahwa tanamana sawi mengalami kejenuhan hara sehingga daun tanaman sawi tidak mampu menyerap hara secara optimal.

Tabel 2. Rata-rata pertumbuhan tanaman dengan dua cara aplikasi POC

\begin{tabular}{ccccccc}
\hline Aplikasi & $\begin{array}{c}\text { Konsentrasi } \\
\text { POC (\%) }\end{array}$ & $\begin{array}{c}\text { TT } \\
(\mathrm{cm})\end{array}$ & $\begin{array}{c}\text { JD } \\
(\text { helai })\end{array}$ & $\begin{array}{c}\text { DB } \\
(\mathrm{mm})\end{array}$ & $\begin{array}{c}\text { LD } \\
\left(\mathrm{cm}^{2}\right)\end{array}$ & TKD \\
\hline Semprot & 0 & 22,69 & 18,08 & 3,97 & 20,35 & 54,54 \\
& 25 & 29,72 & 19,25 & 4,63 & 28,88 & 56,11 \\
& 50 & 23,91 & 21,22 & 3,85 & 17,45 & 52,37 \\
& 75 & 29,75 & 24,75 & 4,46 & 26,15 & 56,66 \\
& 100 & 30,07 & 24,99 & 4,36 & 20,16 & 57,50 \\
Siram & 0 & 32,49 & 27,58 & 4,76 & 19,56 & 50,88 \\
& 25 & 17,13 & 10,91 & 2,99 & 19,67 & 64,39 \\
& 50 & 19,45 & 13,61 & 3,09 & 17,91 & 54,10 \\
& 75 & 27,47 & 23,13 & 4,24 & 19,52 & 53,30 \\
& 100 & 16,54 & 17,63 & 3,23 & 14,36 & 55,74 \\
\hline
\end{tabular}

Pengaruh pemberian pupuk organik cair daun gamal pada minggu ke 1 sampai minggu ke 12 menunjukkan bahwa pertumbuhan diameter batang tanaman masing-masing perlakuan berbeda tidak nyata. Pada minggu ke 12 pemberian POC dengan perlakuan menghasilkan diameter batang tanaman cenderung lebih tinggi dari perlakuan lainnya, sedangkan pada perlakuan $\mathrm{K}_{1} \mathrm{C}_{2}$ menghasilkan diameter terendah. Ada beberapa faktor yang mempengaruhi pertumbuhan tanaman, salah satunya pengaruh cahaya dalam proses fotosintesis. Intensitas naungan secara mandiri menunjukkan pengaruh nyata terhadap variabel tinggi tanaman, jumlah daun, jumlah anakan, berat basah bagian atas tanaman, berat kering bagian atas tanaman, berat basah rimpang, berat kering rimpang jahe. Kekurangan cahaya dapat menyebabkan terhambatnya fotosintesis 
(Putri, 2009) dan kecepatan respirasi (Simanjuntak et al., 2007) sehingga laju pertumbuhan tanaman menjadi rendah.

Pengaruh pemberian pupuk orgnik cair daun gamal terhadap tingkat kehijauan daun dari minggu ke 1 sampai minggu ke 12 mengalami fluktuasi. Perlakuan $\mathrm{K}_{1} \mathrm{C}_{2}$ menunjukkan tingkat kehijaun daun tertinggi sedangkan perlakuan $\mathrm{K}_{0} \mathrm{C}_{2}$ merupakan perlakuan yang menghasilkan tingkat kehijauan daun terendah. Hal ini karena tidak terpenuhinya kebutuhan unsur hara terutama unsur N. Proses pertumbuhan suatu tanaman tergantung oleh ketersediaan unsur hara di dalam tanah. Unsur hara dibutuhkan semakin banyak untuk menunjang proses pertumbuhan lanjutan dan merangsang munculnya organorgan vegetatif (Nopriani, 2016).

Rata-rata luas daun tanaman jeruk gerga tertinggi diperoleh dari perlakuan $\mathrm{K}_{1} \mathrm{C}_{1}$ sedangkan perlakuan $\mathrm{K}_{4} \mathrm{C}_{2}$ menghasilkan luas daun terendah. Hal ini menunjukkan bahwa pupuk organik cair daun gamal pada perlakuan $\mathrm{K}_{1} \mathrm{C}_{1}$ mampu mensuplai kebutuhan unsur hara terutama N. Pada perlakuan $\mathrm{K}_{4} \mathrm{C}_{2}$ unsur hara akan mudah hilang bersama air perkolasi sehingga tidak dapat diserap secara optimal oleh tanaman. Nopriani (2016) menambahkan bahwa proses pertumbuhan suatu tanaman tergantung oleh ketersediaan unsur hara didalam tanah, unsur hara dibutuhkan semakin banyak untuk menunjang proses pertumbuhan lanjutan dan merangsang munculnaya organ-organ vegetatif.

Pertumbuhan jumlah cabang menunjukkan bahwa perlakuan $\mathrm{K}_{2} \mathrm{C}_{2}$ merupakan perlakuan yang lebih tinggi dari perlakuan lainnya sedangkan perlakuan $\mathrm{K}_{4} \mathrm{C}_{2}$ menghasilkan jumlah cabang terendah.. Hal ini menunjukkan bahwa pupuk organik cair daun gamal pada perlakauan $\mathrm{K}_{2} \mathrm{C}_{2}$ mampu mensuplai kebutuhan unsur hara terutama N. Pemberian POC dapat meningkatkan serapan unsur hara terutama unsur hara $\mathrm{N}$ yang sangat diperlukan tanaman, sehingga tanaman dapat memacu pertumbuhan vegetatifnya (Manullang et al., 2014).

Hasil penelitian Nuryenti et al. (2016) menunjukkan bahwa pemberian dosis pupuk organik cair $10 \mathrm{~mL}$ dengan penyemprotan melalui daun dapat meningkatkan produksi tanaman. Sedangkan cara pemberian pupuk organik cair dengan cara siram ke tanah semakin tinggi konsentrasi POC yang diberikan maka pertumbuhannya semakin menurun. Tanaman akan tumbuh baik apabila unsur hara yang dibutuhkan untuk pertumbuhan dan perkembangannya tersedia, seimbang dan dalam konsentrasi yang optimum (Wibawa, 1998).

\section{KESIMPULAN}

Pemberian POC pada konsentrasi 50\% mampu meningkatkan pertumbuhan jumlah cabang.Belum diketahui cara aplikasi POC yang tepat untuk pertumbuhan bibit jeruk gerga. Namun cara aplikasi POC dengan semprot ke daun cenderung lebih baik daripada siram ke tanah. Tidak ada interaksi antara konsentrasi dengan aplikasi POC.

\section{SANWACANA}

Terima kasih kepada Direktorat Riset dan Pengabdian Masyarakat, Direktorat Jendral Penguatan Riset dan Pengembangan, Kementerian Riset, Teknologi dan Pendidikan Tinggi atas bantuan dana riset sesuai dengan Kontrak Penelitian Nomor : 061/SP2H/LT/ DRPM/IV/2017.

\section{DAFTAR PUSTAKA}

Bhargava, B.S. (2002). Leaf analysis for nutrient diagnosis, recommendation and management in fruit crops. J. Indian Soc. of Soil Sci., 50, 35273.

Boerhendhy, I. (2014). Prospek perbanyakan bibit karet unggul dengan teknik okulasi dini. Jurnal Penelitian dan Pengembangan Pertanian, 32 (2), 85-90.

Endarto. O \& Martini, E. (2016). Pedoman Budidaya Jeruk Sehat. Balai Penelitian Tanaman Jeruk dan Buah Subtropika (Balitjestro). Bogor. World Agroforestry Centre

Gomez, K.A. \& Gomez, A.A. (1983). Statistical Procedures for Agricultural Research.John Wiley \& Sons., Singapore.

Hartaman, H. T., Kaster, D.E. \& Davis, Jr., F.T. (1990). Plant Propagation, Principles and Practice. Fifth Edition. Prentice Hall, Inc. Englewoo. New Jersey

Hadisuwito, S. (2017). Membuat Pupuk Organik Cair. Agromeddia Pustaka, Jakarta.

Ibrahim, B. (2002).Intergrasi Jenis Tanaman Pohon Leguminosae Dalam Sistem Budidaya Pangan Lahan Kering dan Pengaruhnya Terhadap Sifat Tanah, Erosi, dan Produktifitas Lahan. Disertasi. Program Pasca Sarjana Universitas Hasanuddin, Makassar.

Juarsah, I. (2014). Pemanfaatan pupuk organik untuk pertanian organik dan lingkungan berkelanjutan. Prosiding Seminar Nasional Pertanian Organik.

Jusuf, L., Mulyati, A.M. \& Sanaba, A.H. (2007). Pengaruh dosis pupuk organik padat daun Gamal terhadap tanaman Sawi.. Jurnal Agrisistem, 3(2), 80-89.

Knaofmone, A. (2016). Pengaruh konsentrasi dan dosis pupuk organik cair terhadap pertumbuhan bibit sengon laut (Paraserianthes falcataria, L.). Savana Cendana, 1(2), 90-92

Manullang, G.S., Rahmi, A. \& Astuti, P. (2014). Pengaruh jenis dan konsentrasi pupuk organik cair terhadap pertumbuhan dan hasil tanaman 
sawi (Brassica juncea L.) varietas Tosakan. Jurnal AGRIFOR, 13(1), 33-40.

Novriani, N. (2016). Pemanfaatan daun gamal sebagai pupuk organik cair (POC) untuk meningkatkan pertumbuhan dan produksi tanaman kubis bunga (Brassica oleracea) pada tanah Podsolik. Klorofil: Jurnal Penelitian Ilmu-Ilmu Pertanian, 11(1), 15-19

Nuryenti, I., Bernas, S.M. \& Sulistiyani, D.P. (2016). Aplikasi Pupuk Organik Cair pada Tanaman Caisim (Brassica juncea) dan Tanaman Selada (Lactuca sativa L.) di Ultisol Lapisan Bawah. Prosiding Seminar Nasional Lahan Suboptimal, 20-21 Oktober, Palembang.

Ohorella, Z. (2012). Pengaruh dosis pupuk organik cair (POC) N kotoran sapi terhadap pertumbuhan dan produksi tanaman sawi ( Brassica sinensis L.). Jurnal Agroforestri, 7(1), 43-49.

Oviyanti, F., Syarifah \& Hidayah, N. (2016). Pengaruh pemberian pupuk organik cair daun gamal (Gliricidia sepium (Jacq.) Kunth ex Walp.) terhadap pertumbuhan tanaman sawi (Brassica juncea L.). Jurnal Biota 2(1)

Pancapalaga, W. (2011). Pengaruh rasio penggunaan limbah ternak dan hijauan terhadap kualitas pupuk cair. Jurnal Gamma, 7(1), 61-68.

Purnomosidhi, P., Suparman, Roshetko, J.M. \& Mulawarman. (2007). Perbanyakan dan Budidaya Tanaman Buah-buahan : Durian, Mangga, Jeruk, Melinjo dan Sawo. Pedoman lapang, edisi kedua. World Agroforestry Centre (ICRAF) \& Winrock Internasional. Bogor, Indonesia.

Putri, I.R. (2009). Pengaruh intensitas cahaya matahari terhadap pertumbuhan jenis Shorea parvifolia dan Shorea leprosula dalam Teknik TPTI Intensif (Studi Kasus di Areal IUPHHK-HA PT. Sarpatim, Kalimantan Tengah). Departemen Silvikultur. Fakultas Kehutanan. Institut Pertanian Bogor, Bogor.

Rambe, S.S.M.R., Supriyanto, A., Calista, L., Ivanti, K. \& Dinata, B. (2012). Laporan Akhir Pengkajian Teknologi Pembungaan dan Pembuahan Jeruk RGL di Lebong. Balai Pengkajian teknologi Pertanian Bengkulu. Balai Besar Pengkajian dan Pengembangan Teknologi Pertanian. Badan Litbang Pertanian. Kementerian Pertanian.

Rini, J. (2014). Pengaruh pemberian pupuk organik hijau dari gamal, lantoro, dan jonga- jonga terhadap produksi dan kualitas rumput gajah (Pennisetum purpureum) pada umur yang berbeda. Skripsi. Fakultas Peternakan Universitas Hasanuddin

Salisbury,B.F. \& Ross, C.W. (1978). Plant Physiology. Wadsworth Pub. Co., Belmont, CA

Simanjuntak, S. H., Prasetyo \& Murcitro, B.G. (2007). Pengaruh dosis pupuk nitrogen dan tingkat naungan terhadap pertumbuhan dan hasil jahe gajah panen muda. Undergraduated thesis. Fakultas Pertanian. Universitas Bengkulu, Bengkulu.

Sutopo. (2008). Rekomendasi pemupukan untuk tanaman jeruk. http://balitjestro.litbang.pertanian.go.id/ rekomendasi-pemupukan-untuk-tanaman-jeruk/

Wibawa, A. (1998). Intensifikasi pertanaman kopi dan kakao melalui pemupukan. Warta Pusat Penelitian Kopi Kakao. 14(3), 245-262.

Wudiyanto, R. (2002). Membuat Stek, Cangkok dan Okulasi. Penebar Swadaya, Jakarta. 